\title{
A RAZOÁVEL DURAÇÃO DO PROCESSO NA JURISDIÇÃO BRASILEIRA ${ }^{1}$
}

\section{THE REASONABLE DURATION OF THE PROCESS IN BRAZILIAN JURISDICTION}

Victor Saldanha Priebe Mestre em Direito pelo Programa de Pós-Graduação Stricto Sensu da Universidade de Santa Cruz do Sul - UNISC, com concentração na área de Direitos Sociais e Políticas Públicas. Integrante do Grupo de Pesquisas "Políticas Públicas no Tratamento dos Conflitos", certificado pelo CNPq, sob a coordenação da Prof. ${ }^{a}$ Pós-Dra ${ }^{\mathrm{a}}$ Fabiana Marion Spengler. Advogado. victor.priebe@ hotmail.com

Fabiana Marion Spengler Pós-doutora em Direito pela Università degli Studi di Roma Tre, em Roma, na Itália, Doutora em Direito pelo programa de Pós-Graduação stricto sensu da Universidade do Vale do Rio dos Sinos - UNISINOS - RS, mestre em Desenvolvimento Regional, com concentração na área Político Institucional da Universidade de Santa Cruz do Sul - UNISC - RS, Brasil, docente dos cursos de Graduação e Pós-Graduação Lato e Stricto Sensu da última instituição, Líder do Grupo de pesquisa "Políticas Públicas no Tratamento dos Conflitos" certificado no CNPQ. Advogada.

fabianaspengler@spengleradvocatio.com.br

RESUMO: O tema central da pesquisa aborda a efetivação da razoável duração do processo por meio das políticas públicas de atenção prioritária do primeiro grau de jurisdição,

\footnotetext{
${ }^{1}$ Artigo recebido em 24/01/2017 e aprovado em 22/06/2017.
} 
Revista Eletrônica de Direito Processual - REDP.

Rio de Janeiro. Ano 11. Volume 18. Número 2. Maio a Agosto de 2017

Periódico Quadrimestral da Pós-Graduação Stricto Sensu em Direito Processual da UERJ

Patrono: José Carlos Barbosa Moreira. ISSN 1982-7636. pp. 165-191

www.redp.uerj.br

tratamento adequado dos conflitos e implantação e avaliação de metas de julgamento, no âmbito do Conselho Nacional de Justiça (CNJ), frente às garantias anteriormente destacadas. Neste passo, o objetivo da presente pesquisa é investigar se tais políticas públicas são adequadas para assegurar a razoável duração do processo sem que sejam descumpridas outras garantias processuais constitucionais, visto que, a problemática que se pretende responder resulta do fato de que o CNJ impõe uma celeridade aos processos pela via de uma adoção equivocada de critérios que podem gerar uma afronta a demais garantias processuais constitucionais. Desta forma, a hipótese desta pesquisa está relacionada ao fato de que as políticas públicas judiciárias implementadas pelo $\mathrm{CNJ}$, ao mesmo tempo em que impõe uma celeridade aos processos pela via de uma adoção equivocada de critérios que pautam o que deve ser considerado como razoável, gera com isto, uma afronta às garantias anteriormente citadas. Por derradeiro, destaca-se que na presente pesquisa foi utilizado o método de abordagem dedutivo combinado com métodos de investigação histórico, comparativo e bibliográfico.

PALAVRAS-CHAVE:Tempos do Direito; Razoável duração do processo; Conselho Nacional de Justiça; Políticas públicas.

ABSTRACT: The central theme of the research is the effectiveness of the reasonable duration of the process through the public policies of priority attention of the first degree of jurisdiction, adequate treatment of conflicts and implementation and evaluation of judgment goals, within the scope of the National Justice Council (CNJ), compared with the guarantees previously mentioned. In this step, the objective of the present research is to investigate if such public policies are adequate to ensure the reasonable duration of the process without other constitutional procedural guarantees being disregarded, since, the problem that is intended to answer results from the fact that the $\mathrm{CNJ}$ imposes a celerity to the processes by means of a mistaken adoption of criteria that can generate an affront to other procedural guarantees constitutional. In this way, the hypothesis of this research is related to the fact that the public judicial policies implemented by the CNJ, while imposing a speed on the processes by means of a mistaken adoption of criteria that guide what should be considered 
Revista Eletrônica de Direito Processual - REDP.

Rio de Janeiro. Ano 11. Volume 18. Número 2. Maio a Agosto de 2017

Periódico Quadrimestral da Pós-Graduação Stricto Sensu em Direito Processual da UERJ

Patrono: José Carlos Barbosa Moreira. ISSN 1982-7636. pp. 165-191

www.redp.uerj.br

reasonable, generates With this, an affront to the aforementioned guarantees. Finally, we highlight that in the present research the method of deductive approach combined with methods of historical, comparative and bibliographic research was used.

KEYWORDS: Times of Law; Reasonable length of process; National Council of Justice; Public policy.

\section{INTRODUÇÃO}

Antes de adentrar-se na tônica central, cabe destacar que é através de uma atuação política que as prestações de serviços públicos podem se tornar mais eficientes. Sendo assim, as políticas públicas são desenvolvidas para o atendimento de demandas sociais que não estão sendo observadas de maneira adequada. Busca-se, através de uma atuação política, a instituição de estratégias de prestação de serviços mais eficientes por parte do Estado.

Deste modo, a temática central aborda a efetivação da razoável duração do processo por meio das políticas públicas de atenção prioritária do primeiro grau de jurisdição, tratamento adequado dos conflitos e implantação e avaliação de metas de julgamento, no âmbito do $\mathrm{CNJ}$, frente às garantias processuais constitucionais de ampla defesa, contraditório e devido processo legal. Assim, a problemática que se pretende responder resulta do fato que o CNJ ao impor uma celeridade aos processos pela via de uma adoção equivocada de critérios poderia gerar uma afronta a demais garantias.

Neste passo, o objetivo geral que se almeja alcançar com a presente pesquisa é investigar se tais políticas públicas são adequadas para assegurar a razoável duração do processo sem que sejam descumpridas outras garantias processuais constitucionais.

Sendo assim, para que se alcance o objetivo pretendido, no primeiro tópico, se aborda a existência de relação entre o tempo social e do Direito, buscando estabelecer ligações destes com tempo do processo, bem como, suas possíveis ligações com a garantia da razoável duração. Na sequência, com o segundo tópico buscou-se analisar as políticas públicas judiciárias implementadas pelo CNJ com a intenção de verificar se estas colocamse como meios aptos para alcançar a razoável duração dos processos. Ao fim, aborda-se de maneira pontual as garantias constitucionais que protegem o processo demonstrando suas várias temporalidades, buscando identificar se estas estão sendo respeitadas pelas políticas 
Revista Eletrônica de Direito Processual - REDP.

Rio de Janeiro. Ano 11. Volume 18. Número 2. Maio a Agosto de 2017

Periódico Quadrimestral da Pós-Graduação Stricto Sensu em Direito Processual da UERJ

Patrono: José Carlos Barbosa Moreira. ISSN 1982-7636. pp. 165-191

www.redp.uerj.br

judiciárias do $\mathrm{CNJ}$ anteriormente citadas, assim como, se tais políticas acentuam os liames interpretativos do julgador, e, ainda, procurando demonstrar os possíveis antídotos adequados para protegeras garantias fundamentais ao mesmo tempo que impõe uma razoável duração aos processos.

Por derradeiro, destaca-se que na presente pesquisa foi utilizado o método de abordagem dedutivo combinado com métodos de investigação histórico, comparativo e bibliográfico, com a intenção de ao fim obter-se uma conclusão em relação ao tema.

\section{TEMPOS DO DIREITO E DO PROCESSO}

\subsection{Tempo social e tempo do direito}

Para que se consiga averiguar se as políticas públicas do CNJ estão de fato implementando a razoável duração aos processos sem que afete demais garantias constitucionais, é necessário primeiramente abordar questões sobre as mais variadas concepções de tempo.

De inicio observa-se a sintetização da concepção de tempo, na qual o tempo é entendido, simbolicamente, através de uma "relação que um grupo de seres vivos dotados de uma capacidade biológica de memória e de síntese estabelecida entre dois ou mais processos, um dos quais é padronizado para servir aos outros como quadro de referência e padrão de medida"2.

No entanto, a partir desta definição que mais se aproximaria de um tempo cronológico, surge um questionamento: por que precisariam os homens determinar o tempo? A resposta para esta indagação, também passa pelo fato de que a determinação do tempo é a expressão de um símbolo social comunicável de questões transdisciplinares que definem posições e trajetórias sucessivas, das quais pautadas pela lei da irreversibilidade necessitam de uma segunda sucessão de acontecimentos individuais para que sejam marcadas por tais modelos sequenciais. Dentro desta resposta, ainda deve ser levado em consideração o fato que a sensação do passar do tempo, possui relevância central em se falando de consciência. ${ }^{3}$

\footnotetext{
${ }^{2}$ SPENGLER, Fabiana Marion. Da Jurisdição à Mediação: por outra cultura no tratamento de conflitos. Ijuí: Unijuí, 2010, p. 180.

${ }^{3}$ Ibidem, p. 181.
} 
Revista Eletrônica de Direito Processual - REDP.

Rio de Janeiro. Ano 11. Volume 18. Número 2. Maio a Agosto de 2017

Periódico Quadrimestral da Pós-Graduação Stricto Sensu em Direito Processual da UERJ

Patrono: José Carlos Barbosa Moreira. ISSN 1982-7636. pp. 165-191

www.redp.uerj.br

Seguindo esta temática, observa-se que "as sociedades, à semelhança do que acontece com as interacções sociais, constroem-se sobre uma multiplicidade de tempos sociais e diferem consoante as combinações e as hierarquias específicas dos tempos sociais que

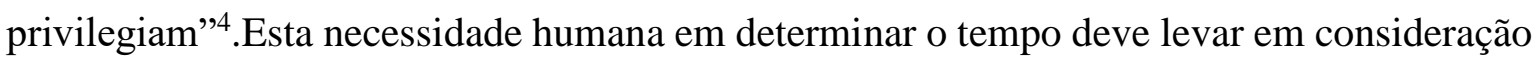
que

[...] aquilo que parece mais relevante, ao invés, é um aspecto que pertence a um jogo inextricável de dependência de tudo; que tudo dependa de tudo é uma ação e somente um evento atribuível a razões passadas e a êxitos futuros, que têm lógicas sempre diferentes e incontroláveis. É uma dimensão da complexidade. O nosso tempo, agora, é um dispositivo de auto-observação que vê explicitamente a introdução visível da variável temporal na complexidade. A despeito de uma aparente incongruência, tempo e complexidade social fazem parte de uma gramática comum 5 .

Tal complexidade social, acima referida, pode ser bem exemplificada com a afirmação de que, a memória é social, e não individual, sendo que ao contextualizar esta afirmação, menciona que as memórias somente têm sentido se partilhadas frente a um coletivo social afetivo, o qual não exita em retrabalhá-las. ${ }^{6}$

Dentro desta complexidade, diz-se que o tempo no mesmo passo que constrói as experiências, define as expectativas. Portanto, as pessoas pertencem ao tempo da mesma forma que este pertence a elas, fazendo com que a determinação haja na mesma intensidade para ambos. No entanto, este discurso não é o único quando se muda a ótica do tempo em direção ao direito, pois neste, deve-se incorporar toda a complexidade de temporalização que as difíceis regras da vida expõem. ${ }^{7}$

Portanto, analisando a temporalização sob a ótica do direito, pode ser acrescentado aos sentimentos acima descritos, as mais variados sensações humanas possíveis, ao passo que, em sendo o tempo do processo um tempo impossível reprodução, abre-se um leque considerável de possibilidades destas, tais como angustia, injustiça.

Contudo, o tempo na forma que atualmente o vemos coloca-se como o elemento que atribui poder a lei, onde o "tempo do processo dá disso uma boa aproximação. Tempo separado do da vida real estreitamente regulado pelas prescrições do ritual, ele permite que

\footnotetext{
${ }^{4}$ SANTOS, Boaventura de Sousa. A gramática do tempo: para uma nova cultura política. 3. ed. São Paulo: Cortez, 2010, p. 68.

${ }^{5}$ RESTA, Eligio. Tempo e Processo. Santa Cruz do Sul: Essere nel mondo, 2014, p. 31.

${ }^{6}$ OST, François. O Tempo do Direito. Lisbôa: Piaget, 1999, p. 59-60.

${ }^{7}$ RESTA, Eligio. Op. Cit., p. 33-34.
} 
Revista Eletrônica de Direito Processual - REDP.

Rio de Janeiro. Ano 11. Volume 18. Número 2. Maio a Agosto de 2017

Periódico Quadrimestral da Pós-Graduação Stricto Sensu em Direito Processual da UERJ

Patrono: José Carlos Barbosa Moreira. ISSN 1982-7636. pp. 165-191

www.redp.uerj.br

o julgamento desenvolva os seus efeitos jurídicos (a condenação, a absolvição) e efeitos sociais"

Por derradeiro, traz-se a afirmação de que "só é possível exprimir o direito dando tempo ao tempo; longe de se resumir ao compasso formal do seu desenrolar cronológico, o tempo é uma das principais apostas da capacidade instituinte do direito", , que por sua vez serve-se do processo para ritualizar suas várias temporalizações.

\subsection{As várias cadências do direito}

Em sendo o tempo uma das principais características instituintes do direito, coube a este, dentro de suas múltiplas realidades, atribuir categorias simples e operacionais que possam servir de base para pautar o seu agir sobre elas. ${ }^{10}$ Dentro destas realidades,

[...] sob o ponto de vista do direito material, inúmeras situações podem surgir. Por exemplo, em matéria contratual, quando as cláusulas contratuais se tornam onerosas ou obsoletas em razão do transcurso do tempo entre a data da realização do contrato e seu cumprimento, ou para definir o início ou término de sua vigência.

Por outro lado, sob a ótica do direito processual, o papel que desempenha é fundamental. Ritos complexos e ordinarizados podem revelar que a política judiciária reflete a escolha pela segurança e pela certeza ${ }^{11}$.

A partir disto, cabe ressaltar a ligação entre a atuação do direito processual e a determinação do que é tempo no contexto social, sendo que ambos exercem a atividade de ação previsível dos acontecimentos transdisciplinares, e ainda definem posições e trajetórias sucessivas. No entanto, “o tempo do processo não é um tempo ordinário. Da mesma forma que o espaço judiciário reconstrói, por oposição ao abandono da sociedade, um interior que encarna a ordem absoluta, o tempo do processo interrompe o escoamento linear do tempo quotidiano" 12 .

Complementando isto, defende-se o direito a seu tempo, o que segundo ele, seria uma prerrogativa negligenciada o fato de cada indivíduo ou grupo poder avançar conforme as suas mais variadas cadências, ou até mesmo, não avançar. ${ }^{13}$

${ }^{8}$ OST, François. Op. Cit., p. 15.

${ }^{9}$ Ibidem. p. 14.

${ }^{10}$ GARAPON, Antoine. Bem Julgar: ensaio sobre o ritual judiciário. Lisbôa: Piaget, 1997, p. 69-70.

${ }^{11}$ SALDANHA, Jânia Maria Lopes. Substancialização e efetividade do direito processual civil: a sumariedade material da jurisdição. Curitiba: Juruá, 2012, p. 242.

${ }^{12}$ GARAPON, Antoine. 1997. Op. Cit., p. 53.

${ }^{13}$ OST, François. Op. Cit., p. 39. 
Revista Eletrônica de Direito Processual - REDP.

Rio de Janeiro. Ano 11. Volume 18. Número 2. Maio a Agosto de 2017

Periódico Quadrimestral da Pós-Graduação Stricto Sensu em Direito Processual da UERJ

Patrono: José Carlos Barbosa Moreira. ISSN 1982-7636. pp. 165-191

www.redp.uerj.br

Isto vai ao encontro da ideia de que o tempo é a condição instituidora do poder da lei, de forma que esta condição somente se manifesta com a força do hábito social em respeitar a lei, portanto exige-se um decurso de tempo para que isto aconteça, e por consequência, faz da nova lei a grande vilã enfraquecedora do poder da lei, o que em momento nenhum pode se considerar que todo o tempo jurídico deve ser um longo tempo. ${ }^{14} \mathrm{Ou}$ seja, é necessário que os hábitos sociais se estabilizem frente a nova concepção ético-jurídica para que o Judiciário na figura do juiz busque dentro das possibilidades interpretativas a que melhor se adéque ao novo contexto, de forma que, a atividade decisória não rompa definitivamente com os hábitos transtemporais instituidores da lei, e portanto, este tempo de estabilização vai estar intimamente ligado com a complexidade que a nova concepção ético-jurídica traz.

Esta atividade decisória respalda a afirmação de que direito é tradição, em um sentido de tempo genealógico, onde este estabelece pelas sedimentações sucessivas de soluções, sendo que as possíveis alterações derivam de argumentos usados no passado do próprio direito. ${ }^{15}$ Sobre isto, orienta-se que

[...] no pensamento jurídico contemporâneo, foi seguramente Ronald Dworkin que desenvolveu este tema com mais eficácia: a concepção do direito como integridade não passa com efeito de um discurso a favor da fidelidade de uma comunidade política aos princípios de moralidade política que inspiram através do tempo o desenvolvimento de suas normas jurídicas ${ }^{16}$.

Neste ínterim, a concepção de direito como integridade não reconhece que para estruturar uma decisão jurídica em casos difíceis deva se olhar somente para o passado, e continua negando que a partir de um olhar somente para o futuro isto aconteça da melhor forma. O que pretende o direito como integridade é combinar os elementos do tempo, passado e futuro, para que se consiga construir uma decisão de acordo com a prática jurídica contemporânea que tem-se em constante desenvolvimento. ${ }^{17}$

Demonstrado isto, fica nítido que o direito possui várias cadências próprias, que por vezes segue um ritmo próprio e por vezes abandona este ritmo, ainda, diferencia-se

\footnotetext{
${ }^{14}$ Ibidem, p. 14-15.

${ }^{15}$ OST, François. Op. Cit., p. 64.

${ }^{16}$ Ibidem, p. 96.

${ }^{17}$ DWORKIN, Ronald. O império do Direito. São Paulo: Martins Fontes, 2007, p. 271.
} 
Revista Eletrônica de Direito Processual - REDP.

Rio de Janeiro. Ano 11. Volume 18. Número 2. Maio a Agosto de 2017

Periódico Quadrimestral da Pós-Graduação Stricto Sensu em Direito Processual da UERJ

Patrono: José Carlos Barbosa Moreira. ISSN 1982-7636. pp. 165-191

www.redp.uerj.br

temporalmente sobre as matérias por ele tratadas, seguindo para um avançar, ou deixar avançar, pautado pela complexidade trazia a ele, porém, é imposto ao direito que atue no presente olhando para o passado sem perder a linha do horizonte que guarda o futuro.

Estando postas as várias cadências/tempos do direito e suas maiores ameaças contemporâneas de destemporalização, "é preciso imaginar mecanismos de concordância dos tempos. No centro da construção jurídica do tempo percebe-se, pois, a pulsação de um ritmo que nos reconduz directamente à figura da temperança"18.

Seria então a garantia constitucional da razoável duração dos processos o mecanismo de concordância que remontaria o sentido da sabedoria dos tempos, significado máximo do termo temperança? É o que passa-se a ver.

\subsection{Origem e conceito da razoável duração dos processos no Brasil}

Diante das mais variadas cadências temporais intrínsecas ao direito e processo vistas no ponto anterior, parte-se aqui em busca do conceito do que pode ser tratado como duração razoável dos processos, bem como, a origem desta no ordenamento jurídico nacional.

Iniciando pela origem da razoável duração dos processos, constata-se que o legislador constitucional na intenção de fazer com que o judiciário trouxesse respostas mais céleres aos jurisdicionados, efetuou uma reforma no poder Judiciário, pela via da Emenda Constitucional 45 (EC45), com as precípuas intenções de impor efetividade e maior controle sobre este. ${ }^{19}$

Com a intenção de satisfazer a necessidade de efetividade, foi introduzida no art. $5^{\circ}$, inc. LXXVIII da Constituição da República Federativa do Brasil de 1988 (CF), a garantia fundamental de razoável duração dos processos, trazendo com isto um conceito não tão moderno de se atribuir celeridade aos processos se compararmos com a origem de tal garantia no cenário jurídico mundial, que aconteceu no ano de 1969, com a publicação do

${ }^{18}$ OST, François. Op. Cit., p. 17.

${ }^{19}$ SPENGLER, Fabiana Marion, 2010. Op. cit., p. 213. 
Revista Eletrônica de Direito Processual - REDP.

Rio de Janeiro. Ano 11. Volume 18. Número 2. Maio a Agosto de 2017

Periódico Quadrimestral da Pós-Graduação Stricto Sensu em Direito Processual da UERJ

Patrono: José Carlos Barbosa Moreira. ISSN 1982-7636. pp. 165-191

www.redp.uerj.br

Pacto de San José da Costa Rica. No entanto, antes mesmo da EC 45/04 (CF), o Brasil havia reconhecido esta garantia quando assinou tal pacto como signatário no ano de $1992 .^{20}$

A partir da falta definição do mandamento constitucional, surge a necessidade de definir critérios para que se consiga estabelecer o que deve se entender por razoável. Desta forma, ganham força “duas hipóteses: “a) tempo razoável é o tempo legal, expressamente previsto na legislação processual; b) tempo razoável é o tempo médio efetivamente despendido no país para cada espécie concreta de processos" ${ }^{\text {21 }}$.

Sobre a segunda hipótese, defende-se que o risco de implementação que este critério traz a convolação do anormal como normal, ou então, considerar-se como razoável, o irrazoável, e ainda assim, torná-lo constitucional, devido a grande morosidade processual que atualmente se presencia no país. ${ }^{22}$ Neste mesmo sentido é o entende-se que o raciocínio mencionando seria a própria negação ao sentido da garantia constitucional de razoável duração dos processos. ${ }^{23}$

Contudo, estabelecendo-se que o prazo razoável é obtido pelo somatório dos prazos processuais, se estaria desconsiderando todas as cadências que no tramite processual possam surgir, pois, "a complexidade da vida e das lides processuais faz com que o prazo razoável somente possa ser indicado caso a caso, mediante um juízo de razoabilidade, somando-se bom senso e ponderação"24.

Desta forma, constitucionalmente autorizado, O CNJ começou a traçar o Plano de Gestão de Varas instituído pela Resolução 70 de 2009 deste órgão ${ }^{25}$, onde mais especificamente no plano que orienta as varas criminais, foi concluído que o prazo razoável quando se tratar de procedimento ordinário deve ficar entre 105 e 148 dias, de forma que, em se tratando de procedimento sumário, este prazo deve ser o de 75 dias, enquanto que no procedimento do júri o prazo razoável para o $\mathrm{CNJ}$ está entre 135 e 178 dias. Tais números

\footnotetext{
${ }^{20}$ COSTA RICA. Convenção Americana de Direitos Humanos, de 22 de novembro de 1969. Pacto de San José da Costa Rica. Disponível em: http://www.cidh.oas.org/basicos/portugues/c.convencao_americana.htm. Acesso em: 10 de out. 2016.

${ }^{21}$ SPENGLER, Fabiana Marion, 2010. Op. cit., p. 216-217.

${ }^{22}$ KOEHLER, Frederico Augusto Leopoldino. A razoável duração do processo. 2. ed. Bahia: Editora JusPODIVM, 2013, p. 116.

${ }^{23}$ SPENGLER, Fabiana Marion, 2010. Op. cit., p. 217.

${ }^{24}$ KOEHLER, Frederico Augusto Leopoldino. Op. Cit., p. 88.

${ }^{25}$ C.N.J. Conselho Nacional de Justiça. Resolução $n^{o}$ 70. 2009a. Disponível em: http://www.cnj.jus.br/buscaatos-adm?documento=2806. Acesso em: 11 out. 2016.
} 
Revista Eletrônica de Direito Processual - REDP.

Rio de Janeiro. Ano 11. Volume 18. Número 2. Maio a Agosto de 2017

Periódico Quadrimestral da Pós-Graduação Stricto Sensu em Direito Processual da UERJ

Patrono: José Carlos Barbosa Moreira. ISSN 1982-7636. pp. 165-191

www.redp.uerj.br

são obtidos pelo somatório simples dos prazos processuais previstos em legislação específica. No entanto, este plano gestor das varas criminais reconhece a possibilidade de situações excepcionais, tanto que, aumenta estes prazos em até 43 dias, de acordo com as especificidades nele descritas. ${ }^{26}$

Desta forma, percebe-se que a posição inicialmente trazida pelo CNJ é de obter, pela via do somatório dos prazos, uma duração razoável dos processos que vise eminentemente uma jurisdição quantitativa, porém, tal conduta mudou de trajetória com a promulgação da Resolução 198 de 2014 por este órgão, onde uma de suas implicações foi de revogar os planos estratégicos instituídos pela Resolução 70, considerando a necessidade de revisões destes. $^{27}$

Esta virada de rumos que o CNJ trouxe com na Resolução 198/14, tem se nítida a intenção de equilibrar suas proposições entre jurisdição quantitativa e qualitativa, quando põe em pé de igualdade as proposições como incentivo às soluções alternativas de litígio e o aumento da quantidade de julgados, para com isto se atingir um cenário respectivamente de desjudicialização e descongestionamento do Poder Judiciário. ${ }^{28}$

Ao fim, nota-se que a definição do que pode ser entendido como razoável somente se alcança analisando diretamente o caso concreto, que através das suas peculiaridades poderá se chegar a uma resposta se a jurisdição está sendo quantitativamente e qualitativamente prestada de modo adequado ${ }^{29}$, de modo que no cenário jurídico nacional, atualmente são dados os primeiros passos nesta direção, sendo que passa-se a analisar os efeitos decorrentes desta nova concepção.

Estando claro que o sentido da razoável duração somente pode ser entendido frente a uma análise caso a caso dos processos, esta concepção fortalece o princípio constitucional de acesso à justiça por conta dos efeitos que irradia, pois, "não basta apenas garantir o acesso aos tribunais, mas principalmente possibilitar aos cidadãos a defesa de direitos e interesses

\footnotetext{
${ }^{26}$ C.N.J.Conselho Nacional de Justiça. Plano de Gestão para o Funcionamento de Varas Criminais e de Execução Penal. 2009b. Disponível em: http://cnj.jus.br/images/programas/justica-criminal/plano-gestaovaras-criminais-cnj.pdf. Acesso em: 09 out. 2016. p. 45-47.

${ }^{27}$ C.N.J. Conselho Nacional de Justiça. Resolução $n^{o}$ 198. 2014a. Disponível em: http://www.cnj.jus.br/buscaatos-adm?documento=2733. Acesso em: 11 out. 2016. p. 01.

${ }^{28}$ C.N.J. Conselho Nacional de Justiça. 2014a. Op. Cit., p. 10.

${ }^{29}$ SPENGLER, Fabiana Marion. 2010. Op. Cit., p. 218.
} 
Revista Eletrônica de Direito Processual - REDP.

Rio de Janeiro. Ano 11. Volume 18. Número 2. Maio a Agosto de 2017

Periódico Quadrimestral da Pós-Graduação Stricto Sensu em Direito Processual da UERJ

Patrono: José Carlos Barbosa Moreira. ISSN 1982-7636. pp. 165-191

www.redp.uerj.br

legalmente protegidos" 30 . Neste mesmo sentido, "uma decisão judicial, por mais justa e correta que seja, muitas vezes pode tornar-se ineficaz quando chega tarde, ou seja, quando é entregue ao jurisdicionado no momento em que não mais interessa nem mesmo o reconhecimento e a declaração do direito pleiteado"31.

Não bastando isto, tais efeitos em prol de uma jurisdição quantitativa e qualitativa adequada, podem ser percebidos no princípio constitucional do devido processo legal no momento em que ressaltam-se os sentidos do "processo justo, isto é, um processo em que seja assegurado um tratamento isonômico, num contraditório equilibrado, em que se busque um resultado efetivo"32, o que não seria possível frente aos curtos prazos que delimitavam o que se entendia por razoável duração.

Aqui, percebe-se que o ajustamento por parte do CNJ agiu-se sob uma perspectiva de requestionamento que desliga as promessas de futuro instituídas por ele mesmo no momento em que determina que o prazo razoável seja o somatório dos prazos processuais, restabelecendo a concepção de tempo das invariantes jurídicas. ${ }^{33}$

Tal cenário somente foi possível de se visualizar com a edição da Resolução 125 de 2010 do CNJ, da qual destaca-se que o investimento está "na conscientização da necessidade de pacificação social, cujos principais objetivos são a qualificação dos serviços prestados à comunidade. O resultado esperado é a construção de uma cultura de autonomia e responsabilização dos conflitantes" ${ }^{34}$.

Frente a isto, percebe-se que o CNJ aproxima-se atualmente do critério para definição do que é razoável duração adotado pelo Tribunal Europeu de Direitos Humanos ${ }^{35}$ (TEDH), que por sua tamanha influência é seguido por outros Tribunais, tais como Corte Interamericana de Direitos Humanos, Corte de Cassação da Itália, Tribunal Constitucional da Espanha dentre outros.

\footnotetext{
${ }^{30}$ Ibidem, p. 218-219.

${ }^{31}$ SPENGLER, Fabiana Marion. Tempo, Direito e Constituição: reflexões na prestação jurisdicional do Estado. Porto Alegre: Livraria do Advogado Editora, 2008, p. 50.

${ }^{32}$ CÂMARA, Alexandre Freitas. Lições de direito processual civil. 23. ed. São Paulo: Editora Atlas, 2012 , p. 49. ${ }^{33}$ OST, François.Op. Cit., p. 18 e 55.

${ }^{34}$ SPENGLER, Fabiana Marion. Retalhos de mediação. Santa Cruz do Sul: Essere nel Mondo, 2014, p. 76.

${ }^{35}$ Critérios de avaliação do TEDH: 1) a complexidade do litígio; 2) a conduta pessoal da parte lesada; 3) a conduta das autoridades envolvidas no processo; e 4) o interesse em jogo para o demandante da indenização. KOEHLER, 2013, p. 91.
} 
Revista Eletrônica de Direito Processual - REDP.

Rio de Janeiro. Ano 11. Volume 18. Número 2. Maio a Agosto de 2017

Periódico Quadrimestral da Pós-Graduação Stricto Sensu em Direito Processual da UERJ

Patrono: José Carlos Barbosa Moreira. ISSN 1982-7636. pp. 165-191

www.redp.uerj.br

Neste passo, adequando-se ao pensamento de que para obter-se uma jurisdição qualitativamente adequada devem também ser desenvolvidos mecanismos que prestem tratamentos aos litígios desta mesma forma ${ }^{36}$, o $\mathrm{CNJ}$ concretiza este posicionamento com a adoção de políticas públicas que garantam a razoável duração dos processos ao mesmo tempo em que tratam de forma adequada os conflitos.

\section{POLÍTICAS PÚblicas do CNJ INSTITUÍdAs EM PROL DA RAZOÁVEL DURAÇÃO DOS PROCESSOS}

\subsection{Política nacional de atenção prioritária do primeiro grau de jurisdição e a não afetação de direitos}

De inicio, passa-se a analisar os seus reflexos da política pública de atenção prioritária ao primeiro grau de jurisdição frente aos direitos e garantias que cercam a a razoável duração dos processos. Para isto, é preciso demonstrar as linhas de atuação que pautam as atividades desta atenção prioritária, as quais encontram-se definidas no art. $2^{\circ}$ da Resolução 194/2014 do CNJ. ${ }^{37}$

De uma maneira geral, as linhas de atuação direcionam suas orientações no sentido de estabelecer uma gestão mais eficiente dos processos que tramitam no primeiro grau, pela via de uma inteligência colaborativa. ${ }^{38}$ No entanto, merece melhor destaque a atuação que estabelece que o poder Judiciário faça uma adequação orçamentária, visto que, é através dela que outras ações podem ser implementadas.

Sobre a adequação orçamentária, a Resolução 195 de 2014 menciona "a importância de se garantir que os recursos organizacionais sejam utilizados equitativamente em todos os segmentos da instituição e com mobilidade suficiente para atender às necessidades temporárias ou excepcionais dos serviços judiciários, como pressuposto do princípio constitucional da eficiência da administração"39.

\footnotetext{
${ }^{36}$ SPENGLER, Fabiana Marion. 2008. Op. Cit., p. 50.

${ }^{37}$ Ver Resolução 194 de 2014. C.N.J. Conselho Nacional de Justiça. Resolução $n^{o} 194$. 2014c. Disponível em: http://www.cnj.jus.br/busca-atos-adm?documento=2483. Acesso em: 12 out. 2016.

${ }^{38}$ C.N.J. Conselho Nacional de Justiça. Relatório final do Grupo de trabalho instituído pela Portaria 155/13. 2013b. Disponível em: http://www.cnj.jus.br/images/imprensa/relatorio_rubens_curado.pdf. Acesso em: 12 out. 2016. p. 10.

${ }^{39}$ C.N.J. Conselho Nacional de Justiça. Resolução $n^{o}$ 195. 2014d. Disponível em: http://www.cnj.jus.br/buscaatos-adm?documento=2482. Acesso em: 12 out. 2016.
} 
Revista Eletrônica de Direito Processual - REDP.

Rio de Janeiro. Ano 11. Volume 18. Número 2. Maio a Agosto de 2017

Periódico Quadrimestral da Pós-Graduação Stricto Sensu em Direito Processual da UERJ

Patrono: José Carlos Barbosa Moreira. ISSN 1982-7636. pp. 165-191

www.redp.uerj.br

Para isto, foi determinado que a distribuição equânime da verba orçamentária deve atender as diretrizes extraídas de uma média de processos novos distribuídos no primeiro e segundo grau de jurisdição, bem como, também deve levar em consideração a média dos processos pendentes, especialmente quando esta diferença entre o primeiro e o segundo grau for superior a $10 \%$. Desta forma, se tais médias apontarem uma inclinação maior para determinado grau de jurisdição, será proporcionalmente inclinado o direcionamento dos recursos não vinculados ${ }^{40}$ naquele sentido. ${ }^{41}$

Nesta linha, cabe destacar que as Resoluções 194/2015 e 195/2014 do CNJ integramse perfeitamente com o vértice interpretativo trazido pelo Código de Processo Civil de 2015 (CPC), no que tange ao princípio da cooperação processual e a ordem cronológica de julgamento.

Isto fica clarividente quando o art. $6^{\circ}$ do $\mathrm{CPC}^{42}$ expõe o modelo cooperativo do processo, sendo que, tal princípio "não se refere à posição de vantagem de qualquer um dos litigantes, mas sim ao respeito aos princípios éticos na atuação processual, em prol da efetividade do processo" ${ }^{43}$. Sob este prisma, entende-se que a organização processual cooperativa necessita de um novo dimensionamento também na sua distribuição, o que implica necessariamente em uma revisão nas cotas de participação que se atribui a cada uma das instâncias participantes do arco processual. ${ }^{44}$

Ademais, também não há falar sobre quebra da ordem cronológica uma vez que o art. $12, \S 2^{\circ}$, inc. VII do CPC determina que estejam excluídas da preferência em ordem cronológica para julgamentos, dentre outros casos, as metas estabelecidas pelo Conselho Nacional de Justiça ${ }^{45}$, as quais serão mais bem abordadas em ponto específico. Deste modo, a eventual quebra de ordem que possa existir em decorrência da observância das Resoluções

\footnotetext{
${ }^{40} \mathrm{Art} .2^{\circ}, \S 1^{\circ}$ : "Entende-se por recursos de natureza não vinculada aqueles destinados ao pagamento de despesas não decorrentes de obrigações constitucionais ou legais." C.N.J. 2014d. Op. Cit.

${ }^{41}$ Ibidem.

42 BRASIL. Congresso Nacional. Código de Processo Civil - Lei 13.105/2015. 2015. Disponível em: http://www.planalto.gov.br/ccivil 03/_ato2015-2018/2015/lei/l13105.htm. Acesso em: 16 maio 2017.

${ }^{43}$ MENDES, Aluisio Gonçalves de Castro; SILVA, Larissa Clare Pochmann da. Normas Fundamentais do Código de Processo Civil de 2015: breves reflexões. p. 47. In: Revista Eletrônica de Direito Processual - REDP. Rio de Janeiro. Ano 10. Volume 17. Número 2. Julho a Dezembro de 1016. Disponível em: http://www.epublicacoes.uerj.br/index.php/redp/article/view/26287. Acesso em: 16 maio 2017.

${ }^{44}$ MARINONI, Luiz Guilherme; ARENHART, Sérgio Cruz; MITIDIERO, Daniel. Novo Código de Processo Civil Comentado. São Paulo : Editora Revistas dos Tribunais, 2015. p. 101.

${ }^{45}$ BRASIL, 2015. Op. Cit.
} 
Revista Eletrônica de Direito Processual - REDP.

Rio de Janeiro. Ano 11. Volume 18. Número 2. Maio a Agosto de 2017

Periódico Quadrimestral da Pós-Graduação Stricto Sensu em Direito Processual da UERJ

Patrono: José Carlos Barbosa Moreira. ISSN 1982-7636. pp. 165-191

www.redp.uerj.br

em pauta, não pode ser entendida como "quebra da impessoalidade e de igualdade: significa simples arranjo de trabalho visando à maior eficiência jurisdicional, que pode inclusive resultar em uma tutela jurisdicional [...] mais tempestiva"46.

Em sendo assim, percebe-se que as linhas de atuação propostas na política pública de atenção prioritária ao primeiro grau de jurisdição em nenhum momento afetam, no sentido negativo, direitos ou garantias processuais fixadas na Constituição ou até mesmo nos princípios dispostos pela legislação processual em si. Muito antes pelo contrário, se coadunam com princípios basilares do processo como o acesso à justiça, devido processo legal e a razoável duração dos processos, no momento em que desenvolvem "em caráter permanente iniciativas voltadas ao aperfeiçoamento da qualidade, da eficiência, da celeridade e da efetividade dos serviços judiciários da primeira instância dos tribunais brasileiros" $" 47$.

Por fim, nas linhas de atuação desta política pública encontram-se menções sobre as outras ações do CNJ que posteriormente serão vista, fato que demonstra o entrelaçamento das proposições em busca de uma jurisdição adequada tanto em termos quantitativos, como qualitativos.

\subsection{Política nacional de tratamento adequado dos conflitos: revolução na efetividade pela via do empoderamento social}

Neste ponto parte-se para a análise da política judiciária nacional de tratamento adequado dos conflitos de interesses buscando quais as contribuições que os tratamentos adequados dos conflitos trouxeram ao judiciário em termos quantitativos e qualitativos.

Isto posto, salienta o CNJ que "o aumento contínuo de casos novos é um desafio que deve buscar soluções alternativas, tais como empreendimentos de conciliação e mediação" 48 . No entanto, salienta-se que a implementação desta política pública esbarra em algumas dificuldades como a estrutura financeira e de pessoal do judiciário, e a resistência social na sua aplicação. ${ }^{49}$

\footnotetext{
${ }^{46}$ MARINONI, Luiz Guilherme; ARENHART, Sérgio Cruz; MITIDIERO, Daniel. 2015. Op. Cit. P. 112. ${ }^{47}$ C.N.J. 2013b. p.16.

48 C.N.J. Conselho Nacional de Justiça. Relatório justiça em Números. 2015. Disponível em: http://www.cnj.jus.br/programas-e-acoes/pj-justica-em-numeros. Acesso em: 13 out. 2016. p. 484.

${ }^{49}$ SPENGLER, Fabiana Marion. 2014. p. 73.
} 
Revista Eletrônica de Direito Processual - REDP.

Rio de Janeiro. Ano 11. Volume 18. Número 2. Maio a Agosto de 2017

Periódico Quadrimestral da Pós-Graduação Stricto Sensu em Direito Processual da UERJ

Patrono: José Carlos Barbosa Moreira. ISSN 1982-7636. pp. 165-191

www.redp.uerj.br

Neste diapasão, percebe-se que a sincronia entre as políticas públicas instituídas pelo CNJ em prol de uma jurisdição qualitativamente e quantitativamente mais adequada, estão em sincronia no que tange a transposição de suas dificuldades, pois, como se viu acima, a política de atenção prioritária ao primeiro grau de jurisdição vem no sentido de readequar a força de trabalho ao mesmo tempo que adéqua a questão orçamentária, o que certamente trará reflexos benéficos aos Centros Judiciários de Solução de Conflitos e Cidadania.

Contudo, não é somente a política pública de tratamento adequado dos conflitos que, potencialmente, sentirá os reflexos benéficos citados. Este contexto também é aproveitado pela Política Nacional de Justiça Restaurativa, uma vez que, a Resolução 225/2016 do CNJ em seu art. $5^{\circ}, \S 1^{\circ}$, atribui aos Tribunais a responsabilidade de disponibilizar recursos humanos e materiais para a concretização e continuidade do programa ${ }^{50}$, que mesmo não sendo o objeto central deste texto merece ser mencionado devido a sua grande relevância dentro dos métodos autocompositivos.

Entretanto, nestas duas políticas públicas citadas identifica-se uma dificuldade em transpor a barreira da aceitação social, pois são "os próprios jurisdicionados que confiam e legitimam apenas o Poder Judiciário como poder soberano, o dono da verdade suprema, que deve decidir e resolver os seus problemas" $" 51$.

Contudo, a Resolução $\mathrm{n}^{\circ} 125$ do $\mathrm{CNJ}$ ao estabelecer o código de ética dos conciliadores e mediadores, estabelece no art. $1^{\mathrm{o}}$ deste, como um dos princípios fundamentais da atuação dos conciliadores e mediadores o empoderamento ${ }^{52}$, definido como uma proposta de

[...] caráter pedagógico que pretende fomentar no cidadão a capacidade/habilidade de se tornar agente de tratamento dos seus conflitos atuais e futuros, a partir da experiência que viveu no âmbito da mediação/conciliação. [...] A ideia é remover os obstáculos estruturais para a participação local e para o exercício do autogoverno. É também proclamada como uma técnica capaz de "administrar a adversidade ${ }^{53}$.

50 C.N.J. Conselho Nacional de Justiça. Resolução 225/2016. 2016. Disponível em: http://www.cnj.jus.br///images/atos_normativos/resolucao/resolucao_225 31052016 02062016161414.pdf.

Acesso em: 16 maio 2017.

${ }^{51}$ SPENGLER, Fabiana Marion. O símbolo, o mito e o rito: o juiz e as "dificuldades epidêmicas" do decidir, p. 134. In. STRECK, L. L.; TRINDADE, A. K.. (org.) Os modelos de juiz: ensaios de direito e literatura. São Paulo: Atlas, 2015, p. 117-139.

${ }^{52}$ C.N.J. Conselho Nacional de Justiça. Resolução $n^{o}$ 125. 2010a. Disponível em: http://www.cnj.jus.br/buscaatos-adm?documento=2579. Acesso em: 13 out. 2016.

${ }^{53}$ SPENGLER, Fabiana Marion. 2014. Op. Cit., p. 91. 
Revista Eletrônica de Direito Processual - REDP.

Rio de Janeiro. Ano 11. Volume 18. Número 2. Maio a Agosto de 2017

Periódico Quadrimestral da Pós-Graduação Stricto Sensu em Direito Processual da UERJ

Patrono: José Carlos Barbosa Moreira. ISSN 1982-7636. pp. 165-191

www.redp.uerj.br

Neste passo, salienta-se que o empoderamento e a emancipação dos indivíduos é evidenciada e incentivada, estes tornam-se mais responsáveis pelo protagonismo nas atividades de cidadania ${ }^{54}$, neste caso representada pelo amplo acesso ao judiciário de forma diversa do que a da jurisdição.

Por fim, percebe-se que as formas de tratamento dos conflitos que inicialmente formam concebidas na intenção de serem mais uma ferramenta de auxílio para o judiciário no combate a crescente litigiosidade, demonstram-se, no entanto, como ferramentas que eficazes também em outros setores da sociedade, pois apostam "numa matriz autônoma, cidadã e democrática" 55 , elevando com isto, os níveis qualitativos de acesso à jurisdição, ao mesmo tempo que, contribui com a celeridade quando trata o conflito sem a necessidade de uma atividade jurisdicional, que encontra-se atualmente com elevados índices de congestionamento.

\subsection{Política de implantação e avaliação de metas de julgamento: o determinismo sob a ótica dos tempos do Direito}

Neste último ponto, estando perfeitamente alinhadas as edições de metas nacionais de julgamento com o conceito definidorde políticas públicas, ressalta-se ainda em tempo, que as metas definidas pelo CNJ não se limitam especialmente a atribuir níveis de processos julgados em um ano, estas também estabelecem níveis de implementação de serviços e métodos de gestão que devem ser observados no ano posterior a edição daquela meta.

No entanto, pretende-se aqui debruçar-se sobre as metas que estabelecem níveis de julgamentos de processos, editadas desde a sua origem no ano de 2009 até a mais atual, editada no ano de 2015 para o exercício no ano de $2016 .{ }^{56}$ Frente a tais metas, percebe-se que estas como se apresentam estão prestes a desrespeitas uma das capacidades instituidoras do direito já mencionada anteriormente, o tempo. ${ }^{57}$ Assim, salienta-se que

\footnotetext{
${ }^{54}$ KONRAD, Letícia Regina.; SCHWINN, Simone Andrea.. Fortalecimento da democracia a partir da esfera pública: comunidade e capital social, p. 216. In. SCHMIDT, J. P.; HELFER, I.. (org.) Comunidade e comunitarismo. Curitiba: Multideia, 2013, p. 215-237.

${ }^{55}$ SPENGLER, Fabiana Marion. 2008. Op. Cit., p. 74-75.

${ }^{56}$ Metas de julgamento instituídas pelo CNJ que estabelecem níveis de julgamento: Meta 1 - Julgar mais processos que os distribuídos; Meta 2 - Julgar processos mais antigos. C.N.J. 2015. Op. Cit.

${ }^{57}$ OST, François. Op. Cit., p. 14.
} 
Revista Eletrônica de Direito Processual - REDP.

Rio de Janeiro. Ano 11. Volume 18. Número 2. Maio a Agosto de 2017

Periódico Quadrimestral da Pós-Graduação Stricto Sensu em Direito Processual da UERJ

Patrono: José Carlos Barbosa Moreira. ISSN 1982-7636. pp. 165-191

www.redp.uerj.br

[...] a necessária valorização da duração poderia induzir uma visão homogénea e lisa do tempo que, no limite, se cristalizaria em breve numa massa cada vez mais inerte, votada à repetição do mesmo, Ora, não podemos ignorar que se faz valer também uma diferente concepção de tempo, infinitamente mais lábil e inventiva: o tempo da instauração e da surpresa, do descontínuo e do aleatório; o tempo das hesitações e das rupturas, das suspensões e dos intervalos ${ }^{58}$.

Portanto, observa-se que o CNJ ao não relacionar a razoável duração dos processos verificada caso a caso com suas metas de julgamento, remetem o raciocínio a "um processo no qual os envolvidos são ouvidos de modo insuficiente, no qual os prazos são calculados de maneira muito curta em que os meios de prova podem ser arbitrariamente excluídos, não garante que a decisão justa seja tomada" ${ }^{\$ 9}$.

Neste passo, apenas apresentam-se mudanças que refletem a uma jurisdição quantitativa, que pela via do "determinismo assume agora a forma da mudança radicalizada: uma mudança valorizada para si mesma, que acarreta uma prodigiosa aceleração dos ritmos temporais e se traduz pela imposição da urgência como temporalidade vulgar"60.

Frente a isto, as metas ao não observarem as cadências que o direito traz consigo, estariam fazendo com que o julgador seja o responsável por guardar mais uma promessa de futuro, pois, "como se sabe, os juízes viram ser-lhes atribuído, ao longo destas últimas décadas, um papel cada vez mais central na rede jurídica: muitas questões, não verdadeiramente resolvidas na lei, são deixadas em definitivo à sua apreciação"61 .

Nesta conjuntura de ampliação dos poderes do juiz somada com a definição de prazo para se efetivar o julgamento da demanda, tem-se por ameaçadas outras garantias constitucionais que circundam o processo, pois, destas é extraído um sentido de que o processo possui suas próprias temporalidades, enquanto aquela impõe ao juiz uma temporalidade máxima. Por fim, passa-se a verificar se o sentido da temperança demonstrase capaz de evitar o conflito de garantias que uma possível discricionariedade do julgador possa trazer no momento de decidir.

\footnotetext{
${ }^{58}$ Ibidem, p. 33.

${ }^{59}$ KIRSTE, Stephan. Introdução à filosofia do Direito. São Paulo: Fórum, 2013, p. 154-155.

${ }^{60}$ OST, François. Op. Cit., p. 35.

${ }^{61}$ Ibidem, p. 188.
} 
Revista Eletrônica de Direito Processual - REDP.

Rio de Janeiro. Ano 11. Volume 18. Número 2. Maio a Agosto de 2017

Periódico Quadrimestral da Pós-Graduação Stricto Sensu em Direito Processual da UERJ

Patrono: José Carlos Barbosa Moreira. ISSN 1982-7636. pp. 165-191

www.redp.uerj.br

\section{ANTÍdOTOS PARA A NECESSÁRIA POLICRONIA DAS GARANTIAS FUNDAMENTAIS}

\subsection{As garantias fundamentais que protegem o processo}

Inicia-se este ponto, buscando demonstrar às várias temporalidades emanadas das garantias fundamentais que cercam o processo. Para tanto, salienta-se que, a decisão judicial somente se trona viável a partir de uma rede de normatividade que possibilite a redução de cognições excessivas. Desta forma, os princípios do sistema normativo oferecem-se como procedimentos de salvaguarda, onde, então, o juiz encontra suas grandes muletas, as quais o dispensam de insuportáveis e contínuos exercícios de cognição. ${ }^{62}$

Deste modo, delimita-se a abordagem sob as garantias processuais constitucionais que exigem uma atenção especial se falando em tempo, sendo elas o princípio do contraditório, princípio da ampla defesa e o princípio do devido processo legal. Certamente as luzes emanadas por estes princípios também atingem de forma reflexiva o princípio da razoável duração dos processos, o qual já foi objeto de análise anteriormente, não cabendo aqui tratá-lo novamente.

Em frente, destaca-se a positivação do princípio do contraditório na $\mathrm{CF} / 88$, mais precisamente no art. $5^{\circ}$, inc. $\mathrm{LV}$, onde também o legislador constitucional optou por expressar o princípio da ampla defesa, mencionando que, "aos litigantes, em processo judicial ou administrativo, e aos acusados em geral são assegurados o contraditório e a ampla defesa, com os meios e recursos a ela inerentes" ${ }^{\prime 63}$.

Em sendo assim, o texto legal menciona que será assegurado o contraditório com os meios e recursos a ela inerentes. Tais meios podem ser considerados como os mecanismos que "o procedimento impõe de maneira bastante precisa a cronologia das intervenções durante o processo" $" 64$.

Entendendo que contraditório é composto por uma série de atos dos quais garantem a oitiva e consequentemente o poder de influência das partes, pode se dizer que este e o princípio da ampla defesa são figuras conexas, "sendo que a ampla defesa qualifica o

\footnotetext{
${ }^{62}$ RESTA, Eligio. Op. Cit., p. 16.

${ }^{63}$ BRASIL. Congresso Nacional. Constituição da República Federativa do Brasil. CF. Disponível em: http://www.planalto.gov.br/ccivil_03/Constituicao/Constituicao.htm. Acesso em: 10 out. 2016.

${ }^{64}$ GARAPON, Antoine. 1997. Op. Cit., p. 61.
} 
Revista Eletrônica de Direito Processual - REDP.

Rio de Janeiro. Ano 11. Volume 18. Número 2. Maio a Agosto de 2017

Periódico Quadrimestral da Pós-Graduação Stricto Sensu em Direito Processual da UERJ

Patrono: José Carlos Barbosa Moreira. ISSN 1982-7636. pp. 165-191

www.redp.uerj.br

contraditório. Não há contraditório sem defesa. Igualmente e lícito dizer que não há defesa sem contraditório. [...] O contraditório e o instrumento de atuação do direito de defesa, ou seja, esta se realiza através do contraditório"65.

Em sequência, passa-se a verificar a garantia constitucional do devido processo legal, consagrado na $\mathrm{CF} / 88 \mathrm{em}$ seu art. $5^{\circ}$, inc. LIV, sob a afirmativa de que "ninguém será privado da liberdade ou de seus bens sem o devido processo legal" (CF).

O princípio de devido processo legal para Didier "tem a função de criar os elementos necessários a promoção do ideal de protetividade dos direitos, integrando o sistema jurídico eventualmente lacunoso. Trata-se da função integrativa dos princípios" ${ }^{66}$. No mesmo sentido, complementa-se que tal princípio "deve ser entendido como uma garantia do trinômio "vida-liberdade-propriedade", através da qual se assegura que a sociedade só seja submetida a leis razoáveis, as quais devem atender aos anseios da sociedade, demonstrando assim sua finalidade social" $" 67$.

Portanto, frente a estes princípios que protegem o processo, a afirma-se que através destes ritos processuais ganham mais sentido, pois, defende-se que no ritual judiciário, se deve buscar manter cada coisa a seu tempo ${ }^{68}$ Contudo, é na afirmação de que "tal como qualquer outro ritual, o processo inverte o curso do tempo. Luta assim contra a finitude devido à sua capacidade para produzir um tempo original, isto é, um tempo que ainda não foi esbatido pelos anos, um tempo indeterminado. O tempo original é o tempo da criação"69.

Ao fim, percebe-se que a ligação dos princípios aqui tratados, induz ao raciocínio de um justo desenrolar, somente oportunizado pela composição harmônica de todos os princípios, sendo isto, uma das interpretações para o sentido do termo temperança. ${ }^{70}$ Estando claro que os princípios constitucionais processuais além se garantir as várias cadências do direito, por vezes as instituem, segue o presente texto em busca das implicações que podem surgir pelas políticas públicas do CNJ em prol da razoável duração dos processos.

\footnotetext{
${ }^{65}$ DIDIER JR, Fredie. Curso de Direito Processual Civil. Vol. 1. 12. ed. Salvador: Editora JusPODIVM, 2010, p. 55 .

${ }^{66}$ Ibidem, p. 44.

${ }^{67}$ CÂMARA, Alexandre de Freiras. Op. Cit., p. 43.

${ }^{68}$ GARAPON, Antoine. 1997. Op. Cit., p. 62.

${ }^{69}$ Ibidem, p. 63.

${ }^{70}$ OST, François. Op. Cit., p. 17.
} 
Revista Eletrônica de Direito Processual - REDP.

Rio de Janeiro. Ano 11. Volume 18. Número 2. Maio a Agosto de 2017

Periódico Quadrimestral da Pós-Graduação Stricto Sensu em Direito Processual da UERJ

Patrono: José Carlos Barbosa Moreira. ISSN 1982-7636. pp. 165-191

www.redp.uerj.br

\subsection{Relações entre o aumento artificial da celeridade instituído pelo CNJ e a possibilidade de aumento na discricionariedade}

Nesta altura do texto onde já se examinou os ganhos e riscos que as políticas públicas do CNJ trazem a jurisdição, inclina-se aqui em busca das relações entre o aumento artificial da celeridade e a possibilidade do aumento da discricionariedade. Cabe salientar desde já que o sentido para o termo discricionariedade aqui usado, advém da atividade judicial em poder escolher mais de uma resposta jurídica ao caso concreto, pois como orienta Streck, "há no direito uma palavra técnica para se referir à escolha: discricionariedade"71.

Observadas as imposições que as políticas públicas do CNJ trouxeram à jurisdição como um todo, vemos que nas duas primeiras, a atenção prioritária ao primeiro grau de jurisdição e o fomento aos tratamentos adequados dos conflitos, estes indubitavelmente atribuíram qualidade na prestação jurisdicional, no momento em que, o primeiro focou-se em gerir melhor a máquina pública do Poder Judiciário, e o segundo empoderou o cidadão com possibilidade de resolver seus conflitos de outra maneira.

Entretanto, como demonstrado anteriormente, a política pública de imposição de metas de julgamento destoa das outras ações, uma vez que, não leva em consideração "esse tempo futuro, que não hesita em sacrificar o presente" ${ }^{72}$. Neste contexto, a tarefa interpretativa que já se tinha por muito ampla, somente poderá ser realizada por um juiz com poder sobre-humano, ou seja, um juiz hercúleo, pois sustenta-se que um juiz real, por mais experiência que tenha não terá a capacidade de uma vez só interpretar de forma plena todo o conjunto normativo que rege a comunidade que este está inserido. ${ }^{73}$

Todavia, a situação se agrava no momento em que o CNJ direciona o cumprimento das metas ao julgador, visto que, "continua-se a apostar na discricionariedade judicial para resolver o problema"74. No entanto, a gravidade e a promessa de futuro não param por aí, uma vez que a Resolução n ${ }^{\circ} 106$ de 2010 do CNJ editada para regulamentar os critérios de aferição de merecimento na promoção dos magistrados aos Tribunais de segundo grau, defini

\footnotetext{
${ }^{71}$ STRECK, Lênio Luiz. O que é isto - decido conforme minha consciência? 4. ed. Porto Alegre: Livraria do Advogado, 2013, p. 112.

${ }^{72}$ OST, François. Op. Cit., p. 228.

${ }^{73}$ DWORKIN, Ronald. Op. Cit., p. 272.

${ }^{74}$ STRECK, Lênio Luiz. Op. Cit., p. 106.
} 
Revista Eletrônica de Direito Processual - REDP.

Rio de Janeiro. Ano 11. Volume 18. Número 2. Maio a Agosto de 2017

Periódico Quadrimestral da Pós-Graduação Stricto Sensu em Direito Processual da UERJ

Patrono: José Carlos Barbosa Moreira. ISSN 1982-7636. pp. 165-191

www.redp.uerj.br

no seu art. $4^{\circ}$, os critérios para a promoção ${ }^{75}$, que dentro deles está o da produtividade, entendido por ela como aspecto quantitativo da prestação jurisdicional. ${ }^{76}$

Além desta classificação na avaliação de produtividade, o CNJ ainda estabelece no art. $11^{\circ}$ da resolução $106 / 10$, que a pontuação pela produtividade poderá chegar a um máximo de 30 pontos, dos quais são divididos entre mais outros quatro critérios chegando a um total de 100 pontos. ${ }^{77}$ Ou seja, é clara a intenção deste órgão em sobrelevar, pelo menos para a promoção, a produtividade na prestação jurisdicional em detrimento a outros tantos aspectos.

Acontece que, a somatória da discricionariedade entendida no positivismo como fatalidade, com a imposição de metas de julgamento que não considerem as cadências intrínsecas do processo, e uma sobrelevação da produtividade derivada das metas de julgamento, resulta em uma ampliação no sentido da discricionariedade, e como lembra Streck, quiçá a uma arbitrariedade. ${ }^{78}$ Desta forma, buscar-se-á a partir de agora os antídotos adequados para proteger as garantias fundamentais do "ataque de funcionalidade" 79 orquestrado pelo $\mathrm{CNJ}$.

\subsection{Direito e processo: os antídotos adequados entre a dualidade de proteção às garantias fundamentais e eficiência}

Na perspectiva do ponto que aqui se inicia, põe-se a investigar se o Direito e processo podem ser considerados ferramentas úteis para proteger garantias fundamentais ao mesmo tempo em que atribuem celeridade à jurisdição.

Seguindo este sentido, entende-se que direito e processo possuem uma relação mais próxima de antídoto, do que, precisamente, veneno um do outro. Deste modo, suas ações

\footnotetext{
${ }^{75} \mathrm{Um}$ dos critérios definidos pelo CNJ para promoção na carreira de juízes estão expostos no art. $6^{\circ}$ da Res. 106/2010. “a) número de audiências realizadas;b) número de conciliações realizadas; c) número de decisões interlocutórias proferidas; d) número de sentenças proferidas, por classe processual e com priorização dos processos mais antigos; e) número de acórdãos e decisões proferidas em substituição ou auxílio no $2^{\circ}$ grau, bem como em Turmas Recursais do Juizados Especiais Cíveis e Criminais; f) o tempo médio do processo na Vara" C.N.J. Conselho Nacional de Justiça. Resolução $n^{o}$ 106. 2010b. Disponível em: http://www.cnj.jus.br/busca-atos-adm?documento=2830. Acesso em: 20 out. 2016.

${ }^{76}$ Ibidem.

${ }^{77}$ Ibidem.

${ }^{78}$ STRECK, Lênio Luiz. Op. Cit., p. 112.

${ }^{79}$ SPENGLER, Fabiana Marion. 2015. Op. Cit., p. 134.
} 
Revista Eletrônica de Direito Processual - REDP.

Rio de Janeiro. Ano 11. Volume 18. Número 2. Maio a Agosto de 2017

Periódico Quadrimestral da Pós-Graduação Stricto Sensu em Direito Processual da UERJ

Patrono: José Carlos Barbosa Moreira. ISSN 1982-7636. pp. 165-191

www.redp.uerj.br

direcionam-se no sentido de "reduzir o arbítrio da punição através da minimização da violência e o respeito de um princípio de exceção do meio. A aposta moderna é aquela de colocar junto garantias e eficiência, procedimento e resultado, respeito dos direitos" $\$ 0$.

Nesta seara, tendo o devido processo legal como princípio constitucional vigente, uma das maneiras de operacionalizá-lo com eficácia é fazendo com que as normas infraconstitucionais repliquem seu sentido de modo a regulamentá-lo. Complementando isto, menciona-se que entre processo e legalidade existe uma ligação muito estreita, da qual a consequência pode ser vista na constitucionalização do processo, fazendo deste um conjunto de regras exprimem de uma forma mais ampla o sentido dos direitos fundamentais de caráter civil e político. ${ }^{81}$

Neste caso, a prestação jurisdicional por meios eletrônicos traria impactos significativos, uma vez que, o gargalo cartorário estaria ao mínimo, sendo tratado. Não obstante isto, cabe aqui ressaltar o reconhecimento pelo $\mathrm{CNJ}$ dos acréscimos que o processo eletrônico pode trazer, tanto que, no seu plano estratégico 2015-2020, coloca entre as tendências atuais dos seus macrodesafios do poder judiciário a intensificação do uso de tecnologia da informação, buscando com isto, um cenário desejado de disseminação da justiça eletrônica. ${ }^{82}$ Contudo, orienta-se que ao acusar o sistema judiciário de ser muito lento, há quem acredite que o antídoto para essa morosidade estaria no tratamento dos processos em tempo real. No entanto, desconsidera-se o fato de que os julgamentos estão cada vez mais inseguros de si, fazendo com que, a necessidade da conclusão dos debates processuais seja cada vez mais negligenciada pela justiça atual. ${ }^{83}$

Voltando a temática central deste ponto, pode-se dizer que no jogo entre direito e processo, as regras essenciais não são aquelas "que definem os lances autorizados e as faltas proibidas, mas as que determinam as convenções fundadoras do jogo: as que habilitam os jogadores e definem os seus poderes respectivos, determinam os riscos, fixam os objectivos

\footnotetext{
${ }^{80}$ RESTA, Eligio. Op. Cit., p. 18.

${ }^{81}$ Ibidem, p. 18.

82 C.N.J. Conselho Nacional de Justiça. Estratégia Judiciário 2020. 2014b. Disponível em: http://www.cnj.jus.br/files/conteudo/destaques/arquivo/2015/03/7694a9118fdabdc1d16782c145bf4785.pdf. Acesso em: 10 out. 2016.

${ }^{83}$ GARAPON, Antoine. 1997. Op. Cit., p. 69.
} 
Revista Eletrônica de Direito Processual - REDP.

Rio de Janeiro. Ano 11. Volume 18. Número 2. Maio a Agosto de 2017

Periódico Quadrimestral da Pós-Graduação Stricto Sensu em Direito Processual da UERJ

Patrono: José Carlos Barbosa Moreira. ISSN 1982-7636. pp. 165-191

www.redp.uerj.br

do jogo" $"$. Logo, frente a este raciocínio, entende-se que a cidadania pode ser expressada como o antídoto aos descaminhos da soberania ${ }^{85}$ das garantias fundamentais, impostos pela celeridade artificial do CNJ.

\section{CONCLUSÃO}

Ao longo de tudo o que foi apresentado, percebe-se que a garantia constitucional da razoável duração dos processos não pode ser entendida como uma técnica que visa simplesmente a aceleração dos processos e procedimentos.

Tem-se, assim, confirmada a hipótese apresentada inicialmente na presente pesquisa, pois como se viu, as políticas públicas judiciárias implementadas pelo CNJ impõe uma celeridade vulgar aos processos, o que de fato não condiz com o conceito da garantia da razoável duração do processo. Não obstante, a hipótese também se confirma quanto a possibilidade de afronta das políticas com as garantias processuais constitucionais trabalhadas, visto que, as cadências desrespeitadas pela celeridade vulgar emanam destes princípios.

Portanto, em resposta a problemática central deste estudo, afirma-se que a adoção equivocada de critérios que busquem estabelecer celeridade aos processos, faz com que a atuação do $\mathrm{CNJ}$ afronte as temporalidades dos princípios trabalhados. Isto se colocou claro no momento em que se verificou que, mesmo as políticas públicas que em seu âmago estão voltadas a uma jurisdição qualitativa, foram instituídas no judiciário nacional sob uma perspectiva eminentemente quantitativa que desconsidera a existência de qualquer tipo de temporalidade extraordinária.

Frente a todo este contexto, respondendo ao objetivo geral da presente pesquisa, qual seja, investigar se as políticas públicas em voga são adequadas para assegurar a razoável duração do processo sem que sejam descumpridas outras garantias constitucionais, concluiuse que da maneira que estão dispostas as políticas públicas que se propôs analisar, a única que não se alinha com a concepção adotada de razoável duração do processo é a política de metas. Entendeu-se assim, pois, nas políticas de priorização do primeiro grau e tratamento

\footnotetext{
${ }^{84}$ OST, François. Op. Cit., p. 90.

${ }^{85}$ GARAPON, Antoine. O juiz e a democracia: o guardião das promessas. 2. ed. Rio de Janeiro: Revan, 1999, p. 260.
} 
Revista Eletrônica de Direito Processual - REDP.

Rio de Janeiro. Ano 11. Volume 18. Número 2. Maio a Agosto de 2017

Periódico Quadrimestral da Pós-Graduação Stricto Sensu em Direito Processual da UERJ

Patrono: José Carlos Barbosa Moreira. ISSN 1982-7636. pp. 165-191

www.redp.uerj.br

adequado dos conflitos houve uma preocupação por uma jurisdição qualitativa que, de uma maneira ou de outra, se equivaleu às aspirações do $\mathrm{CNJ}$ em termos quantitativos, sem que houvesse, portanto, uma afronta aos princípios analisados. Contudo, no tocante a política de metas isto não se verificou, uma vez que, se impôs uma celeridade vulgar vazia de sentido que somada às vinculações subjetivas, agridem diretamente as temporalidades expressadas pelas garantias processuais constitucionais. Portanto, concluiu-se que o contexto da política de metas como está atualmente apresentado, garante uma queda na taxa de congestionamento do Poder Judiciário, mas não propriamente assegura a razoável duração do processo, pois, se coloca como limitadora da atuação dos princípios constitucionais do devido processo legal, do contraditório e da ampla defesa.

\section{REFERÊNCIAS BIBLIOGRÁFICAS:}

BRASIL. Congresso Nacional. Constituição da República Federativa do Brasil. CF. Disponível em: http://www.planalto.gov.br/ccivil_03/Constituicao/Constituicao.htm. Acesso em: 10 out. 2016.

BRASIL. Congresso Nacional. Código de Processo Civil. - Lei 13.105/2015. 2015.

Disponível em: http://www.planalto.gov.br/ccivil_03/_ato2015-2018/2015/lei/113105.htm. Acesso em: 16 maio 2017.

CÂMARA, Alexandre Freitas. Lições de direito processual civil. 23. ed. São Paulo: Editora Atlas, 2012. Volume I.

C.N.J. Conselho Nacional de Justiça. Estratégia Judiciário 2020. 2014b. Disponível em: http://www.cnj.jus.br/files/conteudo/destaques/arquivo/2015/03/7694a9118fdabdc1d16782 c145bf4785.pdf. Acesso em: 10 out. 2016.

Conselho Nacional de Justiça. Plano de Gestão para o Funcionamento de Varas

Criminais e de Execução Penal. 2009b. Disponível em: http://cnj.jus.br/images/programas/justica-criminal/plano-gestao-varas-criminais-cnj.pdf. Acesso em: 09 out. 2016.

Conselho Nacional de Justiça. Relatório final do Grupo de trabalho instituído pela

Portaria 2013b. 155/13. Disponível em: 
Revista Eletrônica de Direito Processual - REDP.

Rio de Janeiro. Ano 11. Volume 18. Número 2. Maio a Agosto de 2017

Periódico Quadrimestral da Pós-Graduação Stricto Sensu em Direito Processual da UERJ

Patrono: José Carlos Barbosa Moreira. ISSN 1982-7636. pp. 165-191

www.redp.uerj.br

http://www.cnj.jus.br/images/imprensa/relatorio_rubens_curado.pdf. Acesso em: 12 out. 2016.

Conselho Nacional de Justiça. Relatório justiça em Números. 2015. Disponível em:

http://www.cnj.jus.br/programas-e-acoes/pj-justica-em-numeros. Acesso em: 13 out. 2016.

. Conselho Nacional de Justiça. Resolução $n^{o}$ 70. 2009a. Disponível em: http://www.cnj.jus.br/busca-atos-adm?documento=2806. Acesso em: 11 out. 2016.

. Conselho Nacional de Justiça. Resolução $n^{o}$ 106. 2010b. Disponível em: http://www.cnj.jus.br/busca-atos-adm?documento=2830. Acesso em: 20 out. 2016.

. Conselho Nacional de Justiça. Resolução $n^{o}$ 125. 2010a. Disponível em: http://www.cnj.jus.br/busca-atos-adm?documento=2579. Acesso em: 13 out. 2016.

- Conselho Nacional de Justiça. Resolução $n^{o}$ 194. 2014c. Disponível em: http://www.cnj.jus.br/busca-atos-adm?documento=2483. Acesso em: 12 out. 2016.

. Conselho Nacional de Justiça. Resolução $n^{o}$ 195. 2014d. Disponível em: http://www.cnj.jus.br/busca-atos-adm?documento=2482. Acesso em: 12 out. 2016.

- Conselho Nacional de Justiça. Resolução $n^{o}$ 198. 2014a. Disponível em: http://www.cnj.jus.br/busca-atos-adm?documento=2733. Acesso em: 11 out. 2016.

. Conselho Nacional de Justiça. Resolução 225/2016. 2016. Disponível em: http://www.cnj.jus.br///images/atos_normativos/resolucao/resolucao_225_31052016_02062 016161414.pdf. Acesso em: 16 maio 2017.

COSTA RICA. Convenção Americana de Direitos Humanos, de 22 de novembro de 1969.

Pacto de San José da Costa Rica. Disponível em: http://www.cidh.oas.org/basicos/portugues/c.convencao_americana.htm. Acesso em: $10 \mathrm{de}$ out. 2016.

DIDIER JR, Fredie. Curso de Direito Processual Civil. Vol. 1. 12. ed. Salvador: Editora JusPODIVM, 2010.

DWORKIN, Ronald. O império do Direito. Trad. Jefferson Luiz Camargo. São Paulo: Martins Fontes, 2007.

GARAPON, Antoine. Bem Julgar: ensaio sobre o ritual judiciário. Lisbôa: Piaget, 1997. O juiz e a democracia: o guardião das promessas. 2. ed. Trad. Maria Luiza de Carvalho. Rio de Janeiro: Revan, 1999. 
Revista Eletrônica de Direito Processual - REDP.

Rio de Janeiro. Ano 11. Volume 18. Número 2. Maio a Agosto de 2017

Periódico Quadrimestral da Pós-Graduação Stricto Sensu em Direito Processual da UERJ

Patrono: José Carlos Barbosa Moreira. ISSN 1982-7636. pp. 165-191

www.redp.uerj.br

KIRSTE, Stephan. Introdução à filosofia do Direito. Trad. Paula Nasser. São Paulo: Fórum, 2013.

KOEHLER, Frederico Augusto Leopoldino. A razoável duração do processo. 2. ed. revisada, ampliada e atualizada. Bahia: Editora JusPODIVM, 2013.

KONRAD, Letícia Regina.; SCHWINN, Simone Andrea.. Fortalecimento da democracia a partir da esfera pública: comunidade e capital social. In. SCHMIDT, J. P.; HELFER, I.. (org.) Comunidade e comunitarismo. Curitiba: Multideia, 2013, p. 215-237.

MARINONI, Luiz Guilherme; ARENHART, Sérgio Cruz; MITIDIERO, Daniel. Novo Código de Processo Civil Comentado. São Paulo : Editora Revistas dos Tribunais, 2015

MENDES, Aluisio Gonçalves de Castro; SILVA, Larissa Clare Pochmann da. Normas Fundamentais do Código de Processo Civil de 2015: breves reflexões. In: Revista Eletrônica de Direito Processual - REDP. Rio de Janeiro. Ano 10. Volume 17. Número 2. Julho a Dezembro de $\quad$ de16. Disponível em: $\underline{\text { http://www.e- }}$ publicacoes.uerj.br/index.php/redp/article/view/26287. Acesso em: 16 maio 2017.

OST, François. O Tempo do Direito. Trad. Maria Fernanda Oliveira. Lisbôa: Piaget, 1999.

RESTA, Eligio. Tempo e Processo. Trad. Fabiana Marion Spengler. Santa Cruz do Sul: Essere nel mondo, 2014.

SALDANHA, Jânia Maria Lopes. Substancialização e efetividade do direito processual civil: a sumariedade material da jurisdição. Curitiba: Juruá, 2012.

SANTOS, Boaventura de Sousa. A gramática do tempo: para uma nova cultura política. 3. ed. São Paulo: Cortez, 2010.

SPENGLER, Fabiana Marion. Da Jurisdição à Mediação: por outra cultura no tratamento de conflitos. Ijuí: Unijuí, 2010.

O símbolo, o mito e o rito: o juiz e as "dificuldades epidêmicas" do decidir. In.

STRECK, L. L.; TRINDADE, A. K.. (org.) Os modelos de juiz: ensaios de direito e literatura. São Paulo: Atlas, 2015, p. 117-139.

Retalhos de mediação. [recurso eletrônico] Santa Cruz do Sul: Essere nel Mondo, 2014.

Tempo, Direito e Constituição: reflexões na prestação jurisdicional do Estado.

Porto Alegre: Livraria do Advogado Editora, 2008. 
Revista Eletrônica de Direito Processual - REDP.

Rio de Janeiro. Ano 11. Volume 18. Número 2. Maio a Agosto de 2017

Periódico Quadrimestral da Pós-Graduação Stricto Sensu em Direito Processual da UERJ

Patrono: José Carlos Barbosa Moreira. ISSN 1982-7636. pp. 165-191

www.redp.uerj.br

STRECK, Lênio Luiz. O que é isto - decido conforme minha consciência? 4. ed. Porto

Alegre: Livraria do Advogado, 2013. 